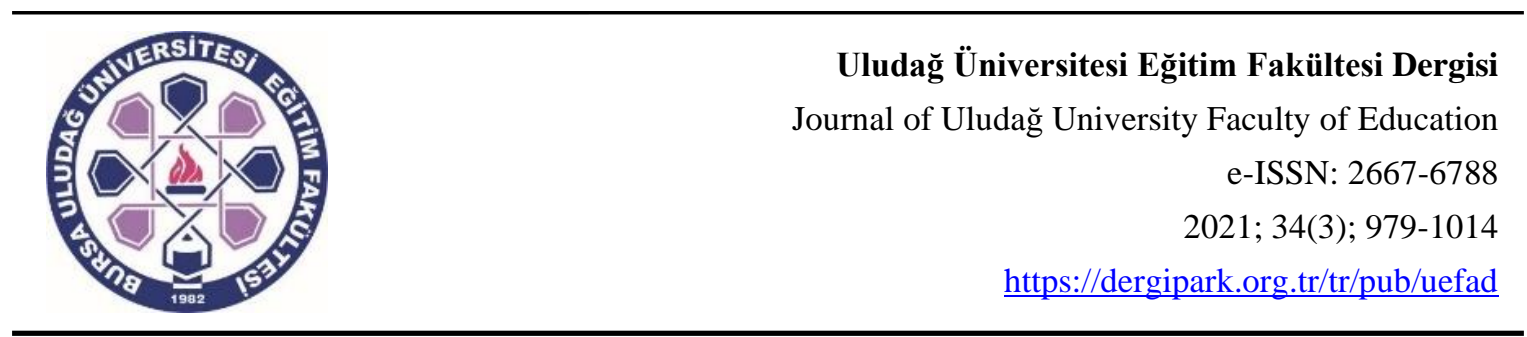

MATEMATIKK ÖĞRETMENLERINIIN 5. SINIFLARDA PROBLEM ÇÖZME

YETERLIKLERİ

\title{
Nuray ÇALIŞKAN DEDEOĞLU ${ }^{1}$, Önder EĞERCi²
}

\begin{tabular}{|c|c|c|}
\hline \multicolumn{2}{|c|}{ Makale Bilgisi } & Özet \\
\hline \multicolumn{2}{|c|}{ Araştırma Makalesi } & $\mathrm{Bu}$ çalışmada, ortaokul matematik öğretmenlerinin 5. sınıflarda problem çözme \\
\hline \multicolumn{2}{|c|}{ DOI: 10.19171/uefad.941549 } & $\begin{array}{l}\text { stratejilerini kullanma yeterlikleri, bu konuda karş1laştıkları zorluklar ve başvurdukları } \\
\text { cözüm vollarına iliskin gelisim süreclerinin incelenmesi amaclanmıstır. Arastırma }\end{array}$ \\
\hline \multicolumn{2}{|c|}{ Makale Geçmişi: } & grubunu, $4+4+4$ eğitim sisteminin uygulanmasiyla ilk kez 5 . sinıflarda ders vermeye \\
\hline Başvuru & 23.05 .2021 & başlayan beş ortaokul matematik öğretmeni oluşturmaktadır. Nitel araştırma desenlerinden \\
\hline Kabul & 27.10 .2021 & $\begin{array}{l}\text { durum çalışması yönteminin benimsendiği çalışmada veriler araştırmacılar tarafindan } \\
\text { hazırlanan Problem Çözme Testi ve Görüşme Formları ile toplanmıș ve betimsel analiz }\end{array}$ \\
\hline \multirow{5}{*}{\multicolumn{2}{|c|}{$\begin{array}{l}\text { Anahtar Kelimeler: } \\
\text { Problem çözme, } \\
\text { Problem çözme } \\
\text { stratejileri, } \\
\text { 5. sınıf, } \\
\text { Ortaokul matematik } \\
\text { öğretmeni. }\end{array}$}} & tekniği ile analiz edilmiştir. Çalışmanın bulguları, öğretmenlerin 5. sınıflarda problem \\
\hline & & çözmede uygun stratejileri kullanabildiğini göstermekle birlikte, strateji çeşitliliğinin \\
\hline & & $\begin{array}{l}\text { öğretmenlerin kidemleri ve farklı sinıf düzeylerinde mesleki deneyimleriyle ilişkili } \\
\text { olduğunu göstermiştir. 5. sinıf düzeyinde daha uzun süre derse giren veya sistem } \\
\text { deŏisikliŏinden }\end{array}$ \\
\hline & & $\begin{array}{l}\text { değişikliğinden sonra mezun olan öğretmenlerin daha farklı stratejiler sergileyebilmiştir. } \\
\text { Bu arastırma, eğitim sistemi değisikliklerinin lisans eğitimi ile uvumlu olmadığ ve hizmet }\end{array}$ \\
\hline & & $\begin{array}{l}\text { Bu araştırma, eğitim sistemi değişikliklerinin lisans eğitimi ile uyumlu olmadığı ve hizmet } \\
\text { içi eğitimle desteklenmediği durumlarda, öğrenci düzeyine uygun öğrenme etkinliklerinin } \\
\text { gerçekleşmesinin öğretmenin kendi çaba ve inisiyatifine bağlı olduğunu ortaya koymuştur. }\end{array}$ \\
\hline
\end{tabular}

\section{PROBLEM SOLVING PROFICIENCY OF MATHEMATICS TEACHERS AT}

\section{5th GRADE}

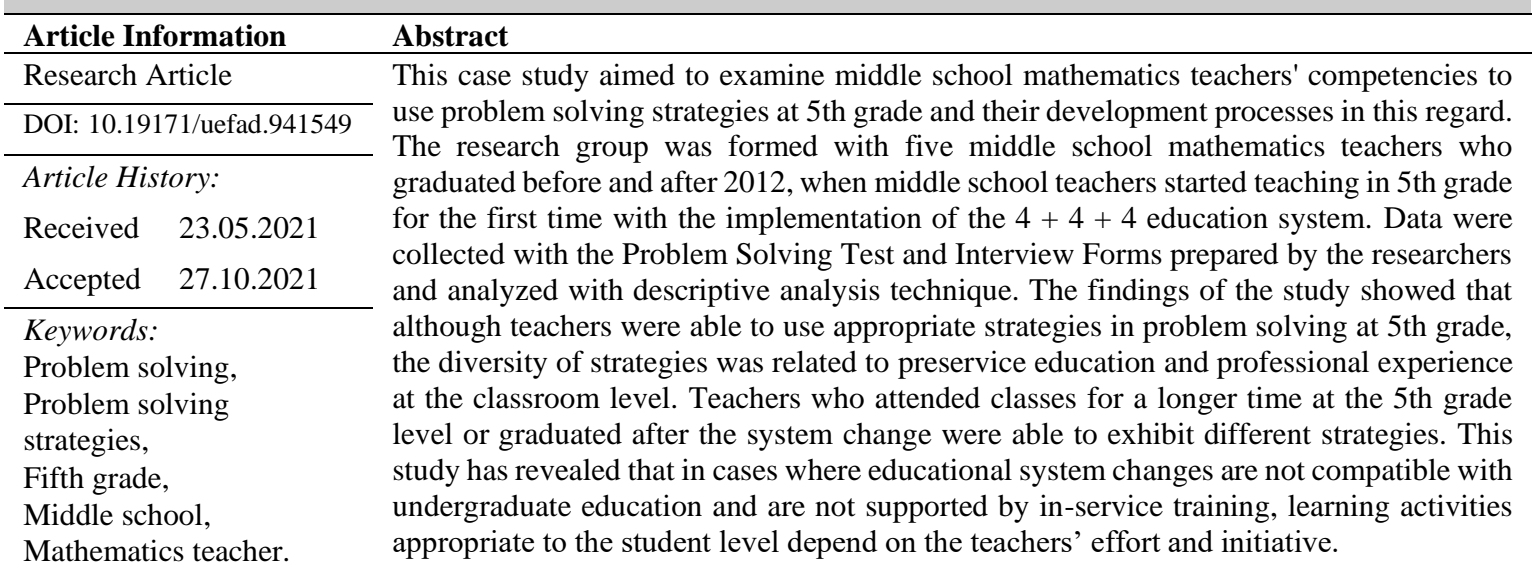

Kaynakça Gösterimi: Çalışkan Dedeoğlu, N., \& Eğerci, Ö. (2021). Matematik öğretmenlerinin 5. sınıflarda problem çözme yeterlikleri. Uludă̆ Üniversitesi Eğitim Fakültesi Dergisi, 34(3), 979-1014. https://doi.org/10.19171/uefad.941549

${ }^{1}$ Dr. Ögr. Üyesi, Sakarya Üniversitesi, ndedeoglu@sakarya.edu.tr, OrcID: 0000-0002-1664-0921

2 Ögretmen, Milli Ĕ̆itim Bakanlı̆̆l, onderegerci@yahoo.com, OrcID:0000-0001-8842-2176 
Citation Information: Çalışkan Dedeoğlu, N., \& Eğerci, Ö. (2021). Problem solving proficiency of mathematics teachers at 5th grade. Journal of Uludağ University Faculty of Education, 34(3), 979-1014. https://doi.org/10.19171/uefad.941549

\section{GíRIŞ}

Türkiye'de 2012-2013 eğitim-öğretim yılında gerçekleştirilen 4+4+4 Eğitim Sistemi Değişikliği (2012 ESD şeklinde kısaltılacaktır) sonucunda, sınıf öğretmenlerinin eğitim verdiği 5. sınıf düzeyi ortaokul kademesine alınmıştır. Bununla birlikte, okula başlama yaşı 72 aydan 66 aya indirilerek veli izniyle 60 aylık çocukların okula başlayabilmesinin önü açılmış (Millî Eğitim Bakanlığı [MEB], 2012) ve böylece, 2012 yılından itibaren ortaokul matematik öğretmenleri daha önce karşılaşmadıkları bir yaş grubuna eğitim vermeye başlamıştır. Millî Eğitim Bakanlığı tarafından, son yıllardaki program değişikliklerinin gerekçelerinden biri, hızlı sosyokültürel, bilimsel ve teknolojik gelişmelerin sonucunda bireyleri farklı becerilerle donanımlı olarak yetiştirme gereği olarak açıklanmıştır (Talim Terbiye Kurulu Başkanlığı [TTKB], 2017). Bireylerde geliştirilmesi gereken önemli becerilerden biri olan problem çözme, gelişmiş ülke matematik müfredatlarının merkezinde yer aldığı gibi, ülkemizde de ortaokul matematik eğitiminin genel amaçları arasında bulunmaktadır (MEB, 2018).

Etkili bir matematik öğretimi ile kazanılan beceriler, günlük hayat veya değişik disiplinlerde uygulama firsatlarının değerlendirilmesini sağlamaktadır. Matematiksel becerilere sahip ve bu becerileri karşılaştığı problemlerde sergileyebilen bireylere her alanda ihtiyaç duyulmaktadır. Matematiğin bireyin düşünme gelişimine, günlük ve gerçek yaşam durumlarına katkısı düşünüldüğünde, bireysel ve toplumsal olarak matematiksel yetkinlik ve dolayısıyla problem çözme önem kazanmaktadır. Öğretmenlerin problem çözme sürecinde farklı stratejiler kullanmaları, öğrencilerin yer aldığı bilişsel dönemlere uygun çözüm sunmaları, matematik öğretiminde birçok açıdan önemli katkı sağlamaktadır (Shulman, 1987). Problem çözmeyi nasıl öğreteceklerini bilen öğretmenler, sınıf ortamında kullandıkları farklı öğretim stratejileri ile daha başarılı öğrencilerin yetişmesini sağlayabilirler (Peterson, Fennema \& Carpenter, 1988). 
Başka bir deyişle, matematik bilgisini geliştiren öğrencilerin, matematik bilgisini iyi kullanan öğretmenleri olduğu söylenebilir (Ma, 1999).

Problem, ilgi çekerek çözme isteği duyulan, çok kolay ya da çok zor olarak algılanmayan, çözüm için gerekli yolların hemen görülemediği doğal durum (Blum \& Niss 1991; Polya, 1957/1997; Posamentier \& Krulik, 2009/2016), problem çözme stratejisi ise problemlere çözüm bulmak için geliştirilen özel yöntemler olarak tanımlanmaktadır (Van de Walle, Karp \& Bay-Williams, 2010/2012). Bir durumun problem olarak algılanabilmesi için öğrencinin ilgisini çekme ve onu zorlayacak bir durum olmanın yanında, bilişsel gelişim dönemine de uygun olmas1 gerekmektedir (Haylock \& Cockburn, 2013/2014; Van de Walle, Karp \& Bay-Williams, 2010/2012). Posamentier ve Krulik’e (2009/2016) göre, problem çözme stratejileri öğrencilerin bilişsel seviyelerine göre değişebilmektedir. Piaget'nin (1971) bilişsel gelişim dönemleri ile ilgili tanımlamasına göre, somut işlemler dönemi 7-11, soyut işlemler dönemi ise 12-16 yaş aralıklarında yer almaktadır. 2012 ESD sonucunda, ortaokul matematik öğretmenlerinin karşılaştığı öğrenci grubunun yaşı bir yaş geriye alınarak en küçük yaş aralığı 10-11 olmuştur. Somut işlemler döneminden soyut işlemler dönemine geçiş evresinde 11-12 yaş aralığı kritik bir yaş olarak kabul edilirken (Wadsworth, 1985/2015), 10-11 yaş aralığ1 tamamen somut işlemler dönemi özelliklerini taşımaktadır. Somut işlemler dönemi öğrencileriyle gelişimlerine uygun stratejilerle problem çözülmeli ve düzeye uygun öğretim yürütülmelidir (Posamentier \& Krulik, 2009/2016). Charles ve Lester (1982), Posamentier ve Krulik (2009/2016), Van de Walle, Karp ve Bay-Williams (2010/2012) somut işlemler dönemine uygun problem çözme stratejilerini; veriyi düzenleme (liste/tablo yapma), tahmin ve kontrol, daha basit denk bir problem çözme, canlandırma veya benzetim, geriye doğru çalışma, çizim yapma, bağıntı (örüntü) bulma, mantıksal akıl yürütme ve farklı bir bakış açısı benimseme şeklinde listelemişlerdir. Soyut işlemler döneminde, bu stratejilere ek olarak, denklem kurma, bağıntı kullanma gibi cebirsel temsillere yer verilen stratejiler 
kullanılabilmektedir. Öğretmenlerin problem çözmede yeterli olabilmesi, problem çözme sürecini geliştirmeye yardımcı olan ve öğrencilerin problem çözme stratejileri konusundaki farkındalıklarını artıracak sistematik eğitimlerle geliştirilebilir (Loucks-Horsley, Hewson, Love \& Stiles, 1998; Owens \& Perry, 2001). 2012 ESD öncesinde, matematik öğretmeni adaylarına genellikle 6, 7 ve 8. sınıf derslerine yönelik eğitim verildiği söylenebilir (Altun, 2008). Öğretmen Yetiştirme ve Geliştirme Genel Müdürlüğü hizmet içi eğitim faaliyetleri incelendiğinde, 2012 yılında değiştirilen veya revize edilen öğretim programlarına yönelik herhangi bir eğitim faaliyetinin planlanmadığı belirlenmiştir (Öğretmen Yetiştirme ve Geliştirme Genel Müdürlüğü [ÖYEGM], 2018). Oysaki öğretmenlerin hizmet içi eğitim almaları matematik öğretiminin nitelikli bir hale gelmesi için önem taşımaktadır.

Nitelikli bir matematik eğitimi, matematiksel kavramlar ve kavramlar arasındaki ilişkileri görebilen, gerekli stratejileri uygulayabilen, edindikleriyle mantıklı çıkarımlar yapabilen ve bunlar yardımıyla problem çözebilen öğrencilerin yetişmesini sağlamalıdır (Schoenfeld, 1989). Öğrenciler, problem çözme sürecinde, problemleri anlama ve matematiksel modelleme ile ifade etmede zorluk yaşamaktadır (Reuter, Schnotz \& Rasch, 2015). Problemin anlaşılabilmesi ve modellenmesinde öğretmenlere önemli görevler düşmektedir. Öğretmenler, problem çözme stratejilerinin seçiminde, öğrencinin bilişsel özelliklerini ve bilgilerini dikkate almalıdır. Öğrencilerin problemleri anlayabilmesi ve problem çözme becerilerine sahip olması için öğretmenler, düzeye uygun öğretim uygulamalarını sergileyebilmelidir. Problem çözümünde belirli yollara yönelerek -çoğu zaman öğrencinin anlamakta zorlandığg- çözüme gitmeye çalışan öğretmenlerin, genelde istenilen duruma ulaşamadıkları bilinmektedir (Van de Walle, Karp \& Bay-Williams, 2010/2012).

Türkiye'de ilköğretim I. kademe 5. sınıf seviyesinin 2012 ESD sonrasında ortaokul seviyesine dâhil edilmesi ile birlikte, ortaokul öğretmenlerine önemli bir mesleki gelişim sorumluluğu yüklenmiştir. İlk kez 5. sınıf seviyesinde matematik öğretimini gerçekleştiren 
öğretmenlerin de sözü edilen zorluklarla karşılaşma olasılıkları yüksektir. Eğitim sistemi değişiklikleri, öğretmenin hizmet öncesi eğitimini ve öğretim bilgisini dikkate almadan hayata geçirildiğinde çeşitli sorunları da beraberinde getirebilir. 2012 ESD ile birlikte ortaya çıkan sorunlar arasında, gelişim seviyesine uygun öğretim stratejilerinin kullanılmaması ve bunun öğrenciler üzerinde olumsuz yansımalara yol açması sayılabilir. Ülkemizde matematik öğretiminin niteliğini artırmak ve Türkiye Yeterlilikler Çerçevesinde (TYÇ) öğrenciler için tanımlanan matematiksel yetkinliğe (TYÇ, 2016) ulaşmak için öğretmenlerin bu süreçte yaşadıkları sorunların tespiti önem kazanmaktadır. Bu çalışma özelinde, öğretmenlerin 5. sınıf düzeyinde problem çözme yeterlikleri ve bu konuda yaşadıkları problemler konu edinilmiştir. Bilinmektedir ki, öğretmenlerin problem çözme yeteneği geliştirildiğinde öğrencilerde olumlu değişimler gözlemlenmektedir (Charles \& Lester, 1984).

Matematik eğitimi alanyazınında, öğretmen ve öğretmen adaylarının problem çözme becerileri ile ilgili birçok çalışma bulunmakta; fakat bunlar arasından öğretmenlerin problem çözme sürecinde tercih ettikleri stratejiler ve bu alandaki mesleki gelişimleri üzerine az sayıda çalışmaya ulaşılmıştır. Öğretmen veya öğretmen adayları üzerine yapılan çalışmalarda, genel olarak sınıf ve ilköğretim matematik öğretmenliği alanında sözel problemlerde değişken kullanmadan problem çözme (Gökkurt Özdemir, Erdem, Örnek \& Soylu, 2017; Soylu, 2010; Tatar, İşleyen \& Okur, 2005) ile problem çözümlerinde strateji veya temsil kullanımındaki çeşitlilik incelenmiştir (Avcu \& Avcu, 2010; Gürbüz \& Güder, 2016; İpek \& Okumuş, 2012; Pusmaz, 2008). Matematik öğretmenlerinin ilk defa karşılaştıkları somut işlemler dönemi özelliklerine sahip öğrencilerle problem çözme alanında yaşadıkları deneyim ve yeterlikleri ile ilgili herhangi bir çalışmaya rastlanmamıştır. $\mathrm{Bu}$ çalışmada, ortaokul matematik öğretmenlerinin 5. sınıflarda problem çözme stratejilerini kullanma yeterlikleri, bu konuda karşılaştıkları zorluklar ve başvurdukları çözüm yollarına ilişkin gelişim süreçlerinin incelenmesi amaçlanmıştır. Buradan hareketle, araştırma problemi "Matematik öğretmenleri 5. 
sınıf düzeyinde problem çözme stratejilerini nasıl kullanmakta, karşılaştıkları zorlukların üstesinden nasıl gelmekte ve gelişimlerini nasıl sağlamaktadır?" olarak belirlenmiştir. Araştırma problemine bağlı olarak oluşturulan alt problemler aşağıda sunulmuştur.

- Öğretmenlerin kullandıkları problem çözme stratejilerinin 5. sınıf düzeyine uygunluğu nasıldır?

- Öğretmenlerin 5. sınıf düzeyinde problem çözmede karşılaştıkları zorluklar ve başvurdukları çözüm yolları nelerdir?

- Öğretmenlerin 5. sınıf düzeyinde problem çözme yeterliklerini kazanmada hangi etmenler nasil rol oynamaktadır?

Çalışmadan elde edilecek bulgular, eğitim sistemi değişikliklerinin mesleki açıdan yansımalarını, öğretmenlerin 5. sınıf düzeyinde problem çözme yeterliklerinin gelişimi bağlamında ortaya koyacaktır.

\section{YÖNTEM}

\subsection{Araştırmanın Deseni}

Araştırmada, sınırları belirli bir sistemin derinlemesine betimlenmesi ve incelenmesi olarak tanımlanan (Merriam, 2009/2015) durum çalışması yöntemi kullanılmıştır. Ele alınan durum, ortaokul matematik öğretmenlerinin problem çözme stratejilerine ilişkin yeterlikleri olarak belirlenmiştir.

\section{2. Çalışma Grubu}

Araştırmada öncelikle ölçüt örnekleme yapılarak 5. sınıf deneyimleri olan matematik öğretmenleri belirlenmiş, ardından maksimum çeşitlilik yoluna gidilmiştir. Maksimum çeşitleme örneklemesindeki amaç, çalışılan probleme taraf olabilecek bireylerin çeşitliliğini maksimum derecede yansıtmaktır (Yıldırım \& Şimşek, 2011). Bu nedenle, kıdem, lisans eğitimi, öğrenim durumu, 2012 yılından önce veya sonra mezun olma durumu dikkate alınarak beş ortaokul matematik öğretmeni araştırma grubuna alınmıştır. Öğretmenler, katılımcı 
gizliliğini sağlamak amacıyla mezuniyet yılı sırasına göre alfabetik olarak Ayşe, Baki, Ceren, Doğan ve Ela öğretmen olarak kodlanmıştır. Araştırma grubunun demografik özellikleri Tablo 1 'de gösterilmiştir.

\section{Tablo 1}

Araştırma Grubunun Demografik Özellikleri

\begin{tabular}{lcccccc}
\hline $\begin{array}{c}\text { Öğretmen } \\
\text { kod adı }\end{array}$ & Cinsiyet & Mezuniyet* & Kıdem & $\begin{array}{c}\text { 5. Sınıf } \\
\text { deneyimi }\end{array}$ & \multicolumn{2}{c}{ Öğrenim durumu } \\
Ayşe & Kadın & $<$ & 11 yıl & 2 yıl & İlköğrt. Mat. & İ̈lköğrt. Mat. \\
Baki & Erkek & $<$ & 10 yıl & 5 yıl & Sınıf öğrt & İlköğrt.Mat. \\
Ceren & Kadın & $<$ & 8 yıl & 6 yıl & İlköğrt. Mat. & İlköğrt. Mat. \\
Doğan & Erkek & $>$ & 3 yıl & 2 y1l & İlköğrt. Mat. & \\
Ela & Kadın & $>$ & 2 y1l & 2 y1l & İlköğrt. Mat. & \\
\hline
\end{tabular}

*<: 2012 öncesi, $>$ : 2012 sonrasi.

Araştırmanın yürütüldüğü 2017-2018 verilerine göre, öğretmenler genel olarak tüm sınıf düzeylerinde en az 2 yıllık deneyime sahipken, yalnızca Doğan 8. sınıf düzeyinde eğitim vermemiştir. Ceren meslek hayatında düzenli olarak bütün sınıf düzeylerinde eğitim vermiş olmakla beraber, 6 yıl ile 5. sınıf düzeyinde en fazla mesleki deneyime sahip öğretmendir. Ceren'i 5 y1l ile Baki takip ederken, Ayşe, Doğan ve Ela 2'şer yıl 5. sınıf düzeyinde mesleki deneyime sahiptir.

\subsection{Veri Toplama Araçları}

Bu çalışmada veri toplama aracı olarak çalışmanın araştırmacıları tarafından geliştirilen problem çözme testi ve iki görüşme formu kullanılmıştır. Problem çözme testinde yer alan problemler, farklı problem çözme stratejilerine imkân verecek şekilde ilgili alanyazın ve ders kaynaklarından seçilmiş ve uyarlanmıştır. Öğretmenlerin problem çözme stratejilerinin belirlenmesi amacıyla geliştirilen problem çözme testi, somut ve soyut işlemler dönemlerinde mümkün olduğunca çeşitli temsil alanlarında (aritmetik, cebirsel, geometrik...) çözümleri 
yapılabilen dört problemden oluşturulmuştur. Bu çalışmada, Charles ve Lester (1982), Posamentier ve Krulik (2009/2016) ve Van De Walle, Karp ve Bay-Williams (2004/2012) tarafindan ortaya konulan somut işlemler dönemine uygun problem çözme stratejileri benimsenmiştir. Tablo 2, araştırmada kullanılan problemleri ve her biri için farklı bilişsel dönemlere uygun olası problem çözme stratejilerini özetlemektedir.

\section{Tablo 2}

Problemlerde Farklı Bilişsel Dönemlere Göre Kullanılabilecek Problem Çözme Stratejileri

\begin{tabular}{|c|c|c|c|c|c|}
\hline & & Problem 1 & Problem 2 & Problem 3 & Problem 4 \\
\hline & & $\begin{array}{l}\text { Aylin ile Selen } \\
\text { doğduklarında } \\
\text { anneleri } 32 \\
\text { yaşında olduğuna } \\
\text { göre kaç yıl sonra } \\
\text { ikizlerin yaş1 } \\
\text { annelerinin yaşının }\end{array}$ & $\begin{array}{l}\text { Aşağıdaki konkav } \\
\text { (içbükey) yedigenin } \\
\text { iç açılarının } \\
\text { toplamını bulunuz. }\end{array}$ & $\begin{array}{l}\text { Aşağıdaki şekilde, }[B C] \perp \\
{[B A],|A B|=4 \mathrm{~cm} \text { ve }|B C|=} \\
2 \mathrm{~cm} \text { olacak şekilde } \mathrm{ABC} \text { dik } \\
\text { üçgeni verilmiştir. }[\mathrm{AX} \text { 1şını } \\
\text { AB doğrusuna diktir. M, [AX } \\
\text { 1şını üzerinde bir nokta olsun. } \\
\text { ACM ücoeni eskenar ücoeni }\end{array}$ & $\begin{array}{l}\text { Birimkarelerle } \\
\text { oluştrumuş } \\
\text { aşağıdaki şekil } \\
\text { üzerindeki taralı } \\
\text { alan kaç } \\
\text { birimkaredir? }\end{array}$ \\
\hline & $\mathrm{C}$ & & $\mathrm{X}$ & $\begin{array}{l}\mathrm{X} \\
\mathrm{X}\end{array}$ & $\begin{array}{l}\mathrm{X} \\
\mathrm{X}\end{array}$ \\
\hline$: \frac{0}{0}: \frac{0}{2}$ & $\mathrm{Bz}$ & X & & & \\
\hline$\vec{\Xi}$ & $\mathrm{T}$ & X & & & \\
\hline है & $\mathrm{L}$ & $\mathrm{X}$ & & & \\
\hline & $\mathrm{M}$ & $X$ & & & \\
\hline$\tilde{\Xi}: \bar{\Xi}$ & Ç & & & X & \\
\hline :윰 : & $\mathrm{F}$ & & & & $X$ \\
\hline 芑 & $\mathrm{Bt}$ & & $X$ & $X$ & $X$ \\
\hline & $\mathrm{D}$ & X & X & & \\
\hline
\end{tabular}

Not. C: Canlandırma, Ç: Çizim, Bz: Benzetim, T: Tahmin/Kontrol, L: Liste yapma, M:

Mantıksal akıl yürütme, F: Farklı bir bakış açısı benimseme, Bt: Bağıntı kullanma, D: Denklem kurma.

Problemlerin her iki bilişsel döneme göre en az üç stratejiyle çözülebileceği belirlenmiştir (ön analizin ortaya çıkardığı olası problem çözme stratejileri için bkz. https://acikerisim.sakarya.edu.tr/handle/20.500.12619/74504). Problem Çözme Testi öncesi ve 
sonrasında uygulanmak üzere yarı yapılandırılmış iki görüşme formu geliştirilmiştir. Görüşme formları Şekil 1'de sunulmuştur.

\section{Şekil 1}

\section{Görüşme Formlarl}

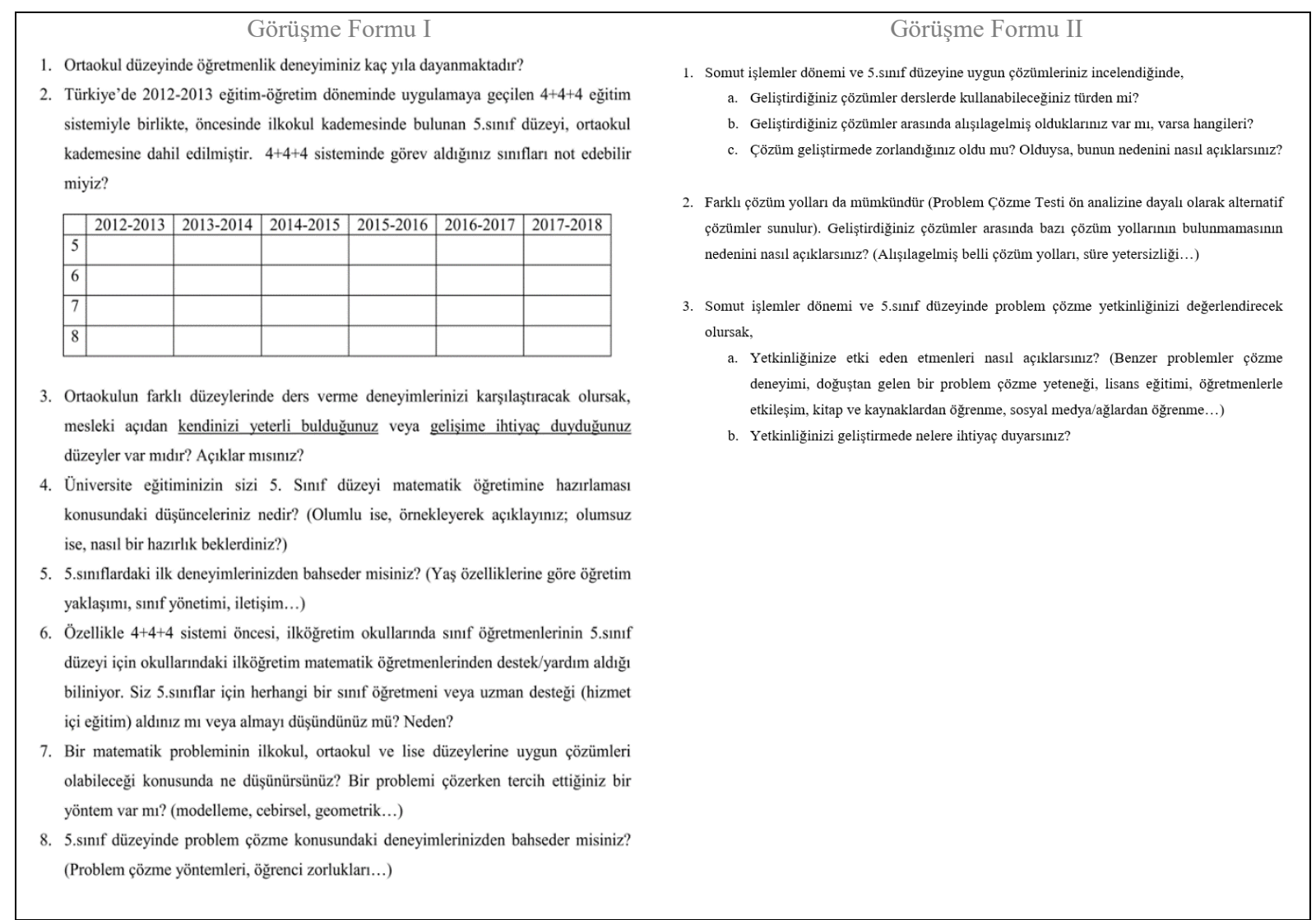

Görüşme formu I, öğretmenlerin kıdemleri, beşinci sınıf düzeyinde ders verme durumları, mesleki eğitimleri, farklı bilişsel seviyelerdeki sınıflara yaklaşımları, mesleki gelişimlerini nasıl sürdürdükleri ve problem çözme konusu hakkında veri sağlamak amaçlıdır. Görüşme formu II ise problem çözme testi uygulamasına ilişkin 5. sınıf düzeyine uygun problem çözme süreçleri ve problem çözme yeterliğinin kazanımı ile ilgili sorulardan oluşturulmuştur. 


\subsection{Veri Toplama Süreci}

Veri toplama süreci, ön görüşme, uygulama ve son görüşme olmak üzere, öğretmenlerin görev yerlerinde, sessiz bir ortamda gerçekleştirilmiştir. Uygulama aşamasında, öğretmenlerden, problemleri süre kısıtlaması ve yönlendirme olmadan, mümkün olduğu kadar farklı çözüm yolları geliştirmeleri ve çözümleri açıklamaları istenmiştir. Öğretmenler problemlere ortalama 12 dakika olmak üzere, 7 ile 28 dakika arasında değişen sürelerde çözüm getirmiştir. Görüşmeler ses kaydı, uygulama aşaması ise video kaydına alınmıştır.

\subsection{Verilerin Analizi}

$\mathrm{Bu}$ çalışmada nitel veri analizi tekniklerinden betimsel analiz tekniği kullanılmıştır. Betimsel analiz tekniğinde araştırmacı, görüşmede elde ettiği bilgi ve yorumları alıntılarla destekleyerek etkili bir sunum amaçlar. Böylece okuyucu arındırılmış ve kanıtlarla sunulmuş bir veri dizisine ulaşmış olur (Yııldırım \& Şimşek, 2006). Araştırmada, Merriam'ın (2009/2015) nitel veri analiz tekniği benimsenerek, görüşme sorularından kategoriler, verilerden de ilgili kategorilere göre kodlar tanımlanmıştır. Çalışmanın ses ve video kayıtları metne çevrilerek, her bir verinin araştırma problemlerine ne tür bilgi sunduğuyla ilgili kodlama yapılmıştır.

Öğretmenlerin problem çözme durumları, problem çözme testinden elde edilen verilerin analizi ile belirlenmiştir. Bu analizde yol gösterici olması amacıyla, problemlerin farklı bilişsel dönemlerde hangi stratejilerle çözülebileceğinin bir ön analizi gerçekleştirilmiştir. Öğretmenlerin kullandıkları stratejiler, ön analizde belirlenen stratejilerle ilişkilendirilerek, farklı bilişsel dönemlere uygun olarak hangilerini kullandıkları belirlenmiştir. Verileri desteklemek için öğretmenlerin görüşlerine ilişkin aktarmalara yer verilmiştir.

\subsection{Geçerlik, Güvenirlik ve Etik}

Geçerlik çalışması, ölçülmek istenen özelliğin ne kadar doğru ölçüldüğünü belirleyen bir çalışmadır (Yıldırım \& Şimşek, 2006). Araştırma amacına ve alt problemlere uygun olarak, uygulanan problem çözme testinde kullanılan problemlerin farklı bilişsel dönemlerde 
çözümlerinin belirlenebilmesi için bir ön analiz gerçekleştirilmiştir. Ön analizde problemler, matematik, matematik öğretmenliği ve ilköğretim matematik öğretmenliği gibi farklı bölümlerden mezun ve farklı mesleki deneyimlere sahip, araştırma grubuyla etkileşimde olmayan dört matematik öğretmeni tarafından çözülmüştür. Elde edilen veriler doğrultusunda problem çözme testine son hali verilmiştir.

Güvenirlik, bir araştırmada her ölçümde aynı sonucun alınmasıdır (Merriam, 2009/2015). Güvenirlik çalışmaları doğrultusunda, araştırma grubundaki öğretmenlerle araştırmanın gizliliği ile ilgili güven ortamı oluşturulmuş, problem çözmeye uygun ortam ve yeterli süre sunulmuştur. Öğretmenlerin yazılı çözümleri ve sözel ifadeleri kaydedilmiş, oluşturulan kodlar açık bir şekilde belirtilmiştir.

Bu araştırma, Sakarya Üniversitesi Etik Kurulu Başkanlığının 03/01/2018 tarih ve 61923333/663.01/78/13 sayılı kararı ile alınan izinle yürütülmüştür.

\section{BULGULAR}

Bulgular, araştırmanın alt problemleri dikkate alınarak üç bölüm halinde sunulmuştur. İlk bölümde, öğretmenlerin kullandıkları problem çözme stratejileri, ikinci bölümde problem çözmede karşılaştıkları zorluklar ve çözüm yolları, son bölümde ise problem çözme yeterliğinin hangi etmenlere bağlı olarak geliştiği ile ilgili bulgulara yer verilmiştir.

\section{1. Öğretmenlerin Kullandıkları Problem Çözme Stratejileri}

Bilişsel gelişim dönemlerine uygun olarak öğretmenlerin çözüm geliştirme durumları Tablo 3'te sunulmuştur. 


\section{Tablo 3}

Öğretmenlerin Bilişsel Gelişim Dönemlerine Ait Çözüm Geliştirme Durumları

\begin{tabular}{|c|c|c|c|c|c|c|c|c|}
\hline \multirow[t]{2}{*}{ Öğretmenler* } & \multicolumn{4}{|c|}{ Somut işlemler dönemi } & \multicolumn{4}{|c|}{ Soyut işlemler dönemi } \\
\hline & $\mathrm{P} 1$ & $\mathrm{P} 2$ & P3 & $\mathrm{P} 4$ & $\mathrm{P} 1$ & $\mathrm{P} 2$ & $\mathrm{P} 3$ & $\mathrm{P} 4$ \\
\hline Ayşe & $\mathrm{X}$ & & $\mathrm{X}$ & & $\mathrm{X}$ & $X$ & $X$ & $\mathrm{X}$ \\
\hline Baki & $\mathrm{X}$ & $X$ & $\mathrm{X}$ & $X$ & $X$ & & $X$ & \\
\hline Ceren & $\mathrm{X}$ & $\mathrm{X}$ & $\mathrm{X}$ & $\mathrm{X}$ & $\mathrm{X}$ & $\mathrm{X}$ & $\mathrm{X}$ & $\mathrm{X}$ \\
\hline Doğan & $X$ & $\mathrm{X}$ & $X$ & $X$ & $\mathrm{X}$ & $X$ & $X$ & $\mathrm{X}$ \\
\hline Ela & $X$ & $\mathrm{X}$ & $\mathrm{X}$ & & $\mathrm{X}$ & $\mathrm{X}$ & $\mathrm{X}$ & $\mathrm{X}$ \\
\hline
\end{tabular}

Not. P1, P2, P3, P4: Problem Çözme Testinde bulunan problemlerin kısaltmaları; X:

Gerçekleştirilmiş çözüm. *Ayşe, Baki ve Ceren 2012 öncesi, Doğan ve Ela ise 2012 sonras1 mezun öğretmenlerdir.

Tablo 3 incelendiğinde, öğretmenlerin ortaokul kademesindeki somutlsoyut işlemler dönemine uygun ve mümkün olan çözümleri büyük oranda sergileyebildiği görülmektedir. Öğretmenler bir problemin farklı bilişsel dönemlere ait çözümlerinin olabileceğini ve bunun öğretimi zenginleştireceğini ifade etmişlerdir. Ayşe ve Ela'nın somut işlemler, Baki'nin ise soyut işlemler dönemindeki çözümleri tüm problemler için tamamlayamadığı görülmektedir. Bu sonuç Baki’nin lisans eğitimiyle (sınıf öğretmenliği) ilişkili gözükmektedir.

Öğretmenler, 5. sınıf düzeyinde modelleme stratejisi (canlandırma ve benzetim), 7 ve 8 . sınıf düzeylerinde ise cebirsel işlem içeren stratejileri (denklem kurma, bağıntı kullanma...) kullanma eğiliminde olduklarını belirtmiştir. Aşağıda bununla ilgili bazı öğretmen görüşlerine yer verilmiştir.

Modellerle anlatıyorum 5. sınıflarda problemleri... 7 ve 8 için cebirsel kullanıyorum (...) problemin çözümünde tabii ki seviye seviye farklılıklar olacaktır. Bir 5. sınıfa çözmenizle bir 8. sınıfa çözmeniz aynı olmaz aynı tipteki bir problemi.” (Ayşe)

"Yani şimdi eee modelleme yapıyoruz mesela beşinci sınıflarda mutlaka harf kullanmiyorsun. (Baki) 
Beşlere mesela onu (kutucuklarla modelleme) kullanamıyorum onunla bile çünkü anlamayabiliyorlar (...) 8. sınıfta bir şeyi harflerle anlatıyorsunuz ama 5. sınıfta daha bir sayının okunuşunu anlatmanız gerekiyor. (Ceren)

Bu bilinmeyenleri, cebirsel ifadeleri beş ve altılara kullanmak hakikaten sıkıntılı oluyor. (Doğan)

Beşinci sınıfta cebirsel yok zaten, modelleme onlara. (Ela)

Öğretmenlerin Problem Çözme Testinde geliştirdiği çözümler incelendiğinde, cebirsel çözümlerle (denklem kurma ve bağıntı kullanma) başlama ve ilk olarak hızlıca cevabı bulma eğiliminde oldukları, sonrasında ise sınıf seviyelerine göre çözümü uyarlamak için farklı stratejiler kullandıkları belirlenmiştir. Öğretmenlerden Baki, bu durumu "kendini garantiye alma” olarak tanımlamıştır. Öğretmenler problemlere cebirsel yollarla çözüm aramalarında eski alışkanlıkları ve merkezi sınavlara yönelik yapılan çalışmaların etkili olduğunu ifade etmiştir. Problem Çözme Testinin çözümünde öğretmenlerin somut işlemler dönemine uygun olarak kullandıkları stratejiler Tablo 4’te sunulmuştur. 


\section{Tablo 4}

Problemler Bazında Öğretmenlerin Somut Işslemler Dönemi Problem Çözme Stratejileri

\begin{tabular}{|c|c|c|c|c|c|c|c|}
\hline & \multicolumn{4}{|c|}{$\mathrm{P} 1$} & $\mathrm{P} 2$ & P3 & $\mathrm{P} 4$ \\
\hline Stratejiler & $\mathrm{Bz}$ & $\mathrm{T}$ & $\mathrm{L}$ & $\mathrm{M}$ & Ç & Ç & Ç \\
\hline Ayşe & $\mathrm{X}$ & & & & & $X$ & \\
\hline Baki & $X$ & & $X$ & & $X$ & $X$ & \\
\hline Ceren & $\mathrm{X}$ & $\mathrm{X}$ & $X$ & & $X$ & $X$ & $X$ \\
\hline Doğan & $X$ & & $X$ & & $X$ & $X$ & $X$ \\
\hline Ela & & $X$ & $X$ & $X$ & $X$ & $X$ & \\
\hline
\end{tabular}

Not. P1, P2, P3, P4 Problem çözme testinde bulunan problemlerin kısaltmalarıdır. Ç: Çizim,

Bz: Benzetim, T: Tahmin/Kontrol, L: Liste yapma, M: Mantıksal akıl yürütme.

Öğretmenlerin 5. sınıf düzeyine uygun olacak şekilde çözümlerde farklı stratejiler kullandıkları ve bu süreçte problem çözme adımlarını takip ettikleri belirlenmiştir.

Öğretmenler problem 1 için 5. sınıf düzeyine ait geliştirdikleri çözümlerde benzetim (modelleme) ve liste yapma stratejileri daha çok olmakla birlikte olası bütün stratejileri kullanmışlardır. Baki, Ela ve Ceren'in Problem 1'e ait farklı problem çözme stratejilerini örneklendiren çözüm görüntüleri Şekil 2'de verilmiştir. 


\section{Şekil 2}

Problem 1 İçin Baki, Ela ve Ceren'in Kullandıkları Çözüm Stratejileri

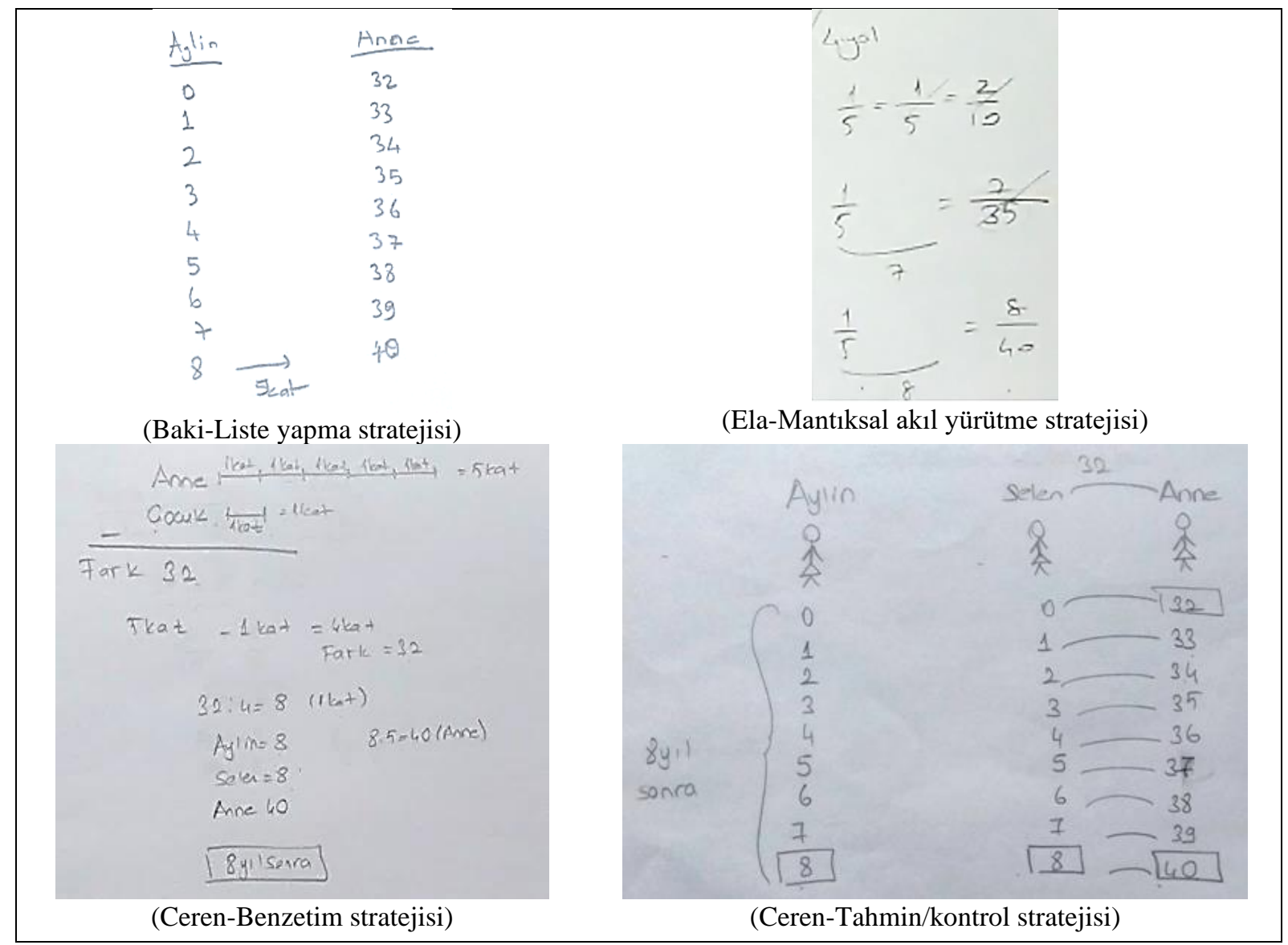

Problemlerin ön analizinde, önerilen dört farklı çözüm stratejisi arasından her öğretmen 1 ila 3 arasında çözüm geliştirebilmiştir. Öğretmenlerin liste yapma ile benzetim stratejisini daha fazla tercih ettiği belirlenmiştir. Problemlere ortaokulun tüm sınıf düzeylerinde çözüm geliştirmek istediğini belirten Ela, diğer öğretmenlerden farklı olarak, iki stratejinin yanı sıra mantıksal akıl yürütme stratejisini de kullanmıştır.

Öğretmenlerin problem 2 için 5. sınıf düzeyinde geliştirdikleri çözümler incelendiğinde, ön analizde önerilen çizim yapma stratejisinin kullanıldığı belirlenmiştir. Örnek bir çözüm olarak Ceren'in çözümü Şekil 3'de sunulmuştur. 


\section{Şekil 3}

Problem 2 İçin Ceren'in Kullandı̆̆ Çizim Yapma Stratejisi

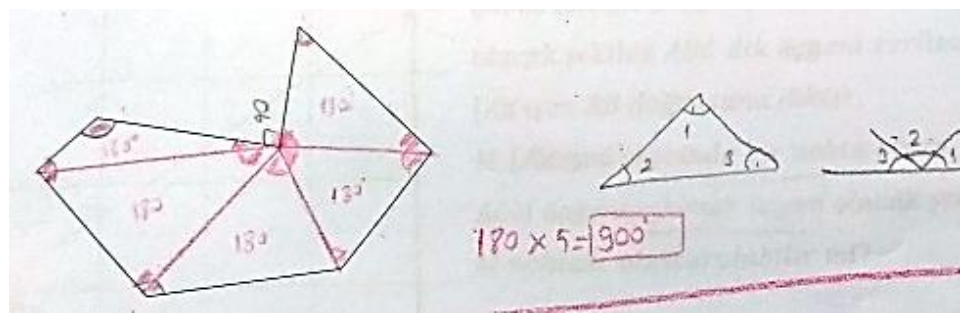

Öğretmenler, problem 3 'ün çözümünde pergel, açıölçer, cetvel ve kareli kağıt araçlarını kullanarak çizim yapma stratejisini kullanmışlardır. Örnek olarak Ceren ve Doğan’ın çözümleri Şekil 4'te sunulmuştur.

\section{Şekil 4}

Problem 3 İçin Ceren ve Doğan'ın Kullandıkları Çizim Yapma Stratejileri

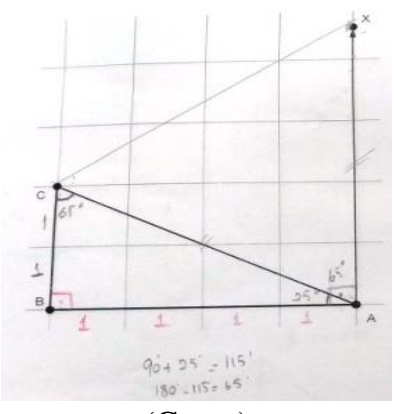

(Ceren)

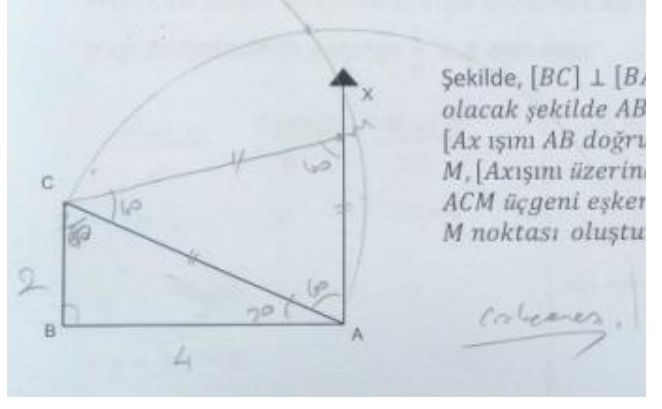

(Doğan)

Problem 4 için Ceren ve Doğan'ın birer çözüm geliştirebildiği, diğerlerinin ise geliştiremediği belirlenmiştir. Ceren canlandırma, Doğan ise çizim yapma stratejisini kullanmıştır (Şekil 5). Bu stratejiler, problemin çözümü için ön analizde belirlenen stratejilerdir. 


\section{Şekil 5}

Problem 4 İçin Ceren ve Doğan'ın Kullandıkları Stratejiler

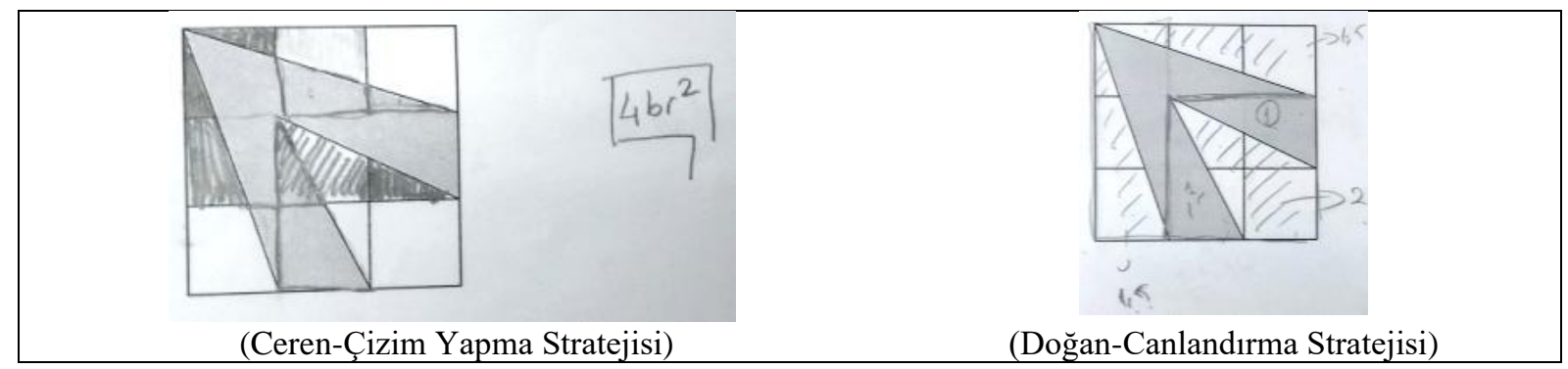

Doğan, "bir dikdörtgensel bölgenin köşegeni, alanını iki eş bölgeye ayırır” bilgisinden yola çıkarak, taralı olmayan alanları köşegenler yardımıyla hesaplayıp tüm şeklin alanından çıkararak çözüme ulaşmıştır. Canlandırma stratejisini kullanan Ceren ise kâğıt katlama ve alan taşımayı kâğıdı keserek gösterme yolunu seçmiş ve kesme işlemi öncesinde kesilecek parçaların bazı bölümlerini tarayarak belirtmiştir. Diğer öğretmenler, probleme soyut işlemler dönemine uygun birer çözüm geliştirirken, somut işlemler dönemine uygun çözüm geliştiremeyeceklerini belirtmişlerdir.

\section{2. Öğretmenlerin 5. Sınıf Düzeyinde Problem Çözmede Karşılaştıkları Zorluklar}

Öğretmenlerin belirttiği ilk zorluk, öğrencilerin problemleri anlamada yaşadıkları sorunlardır. 5. sınıf öğrencilerinin diğer sınıf düzeylerindeki öğrenciler gibi problemleri anlamadığını belirten öğretmenlerin bu tespiti, öğrencilerin yer aldıkları bilişsel gelişim dönemleriyle açıklanabilir.

(Beşinci sınıfta) çocuklar çok fazla cümle kurduğumda ... birçok şeyi söylediğinde anlayamiyorlard1. (Ceren)

Anlamadıklarında aynı şeyi bir daha alıyorsun baştan bir daha alıyorsun baştan daha da alta nasıl inebilirim daha da düşük seviye nasıl gidebilirim diye. (Doğan)

Problemi anlama konusunda öğrencilerin problem çözmede, sözel ve uzun ifadeleri anlamakta zorlandıklarını belirten öğretmenlerin bu zorlukla ilgili örnek ifadeleri sunulmuştur. 
Bence (sözel ifadeleri) canlandırdıklarını düşünmüyorum. (Baki)

İletişim konusunda da yalnız çocuklar çok fazla cümle kurduğumda işte pek fazla hani aynı anda birçok şeyi söylediğinde anlayamıyorlardı. (Ceren)

2012 ESD öncesi mezun öğretmenler, ilk 5. sınıf öğretim deneyimlerini “zor, bilinmeyen” şeklinde tanımlamışlardır. Bu zorluğu aşmak için farklı yöntemleri denediklerini ve zamanla en doğru yolu bulduklarını belirten öğretmenler, bir sınıf düzeyindeki eksikliklerin uzun süre derse girerek giderilebileceğini belirtmişlerdir. Ayşe, problemlere farklı stratejilerle çözüm geliştiremediği durumları "Yani beşlere girme açısından da 2 yıl girdiğim için de az tecrübem var onunla ilgili” şeklinde açıklamıştır. 5. sınıf düzeyinde ilk olarak küçük yaşta öğrencilerin okula başlamasından kaynaklanan ve sınıfta farklı yaşta öğrencilerin bir arada yer almasıyla sonuçlanan durumdan dolayı zorluk yaşadığını belirtmiştir. Bu durumu Baki, “Okula başlama yaşını etkili olduğunu düşünüyorum çünkü bir sınıfta bir yaş küçük olan öğrenciler varsa gerçekten o öğrenciler diğerlerine göre geri kalıyorlar. Yaş faktörü çok önemli.” şeklinde ifade etmiştir. 2012 ESD öncesi mezun öğretmenler 7. ve 8. sınıf düzeyinde, 2012 ESD sonras1 mezun öğretmenler ise en çok 5. sınıf düzeyinde olmakla birlikte tüm sınıf düzeylerinde kendilerini yeterli hissettiklerini belirtmişlerdir. 2012 ESD sonrası mezun ile çift ana dal mezunu (sınıf ve ilköğretim matematik öğretmenliği) öğretmenler yeterli bir lisans eğitimi aldıklarını, bu sebeple 5. sınıf düzeyinde problem çözmede zorlanmamalarına rağmen ders kitaplarındaki etkinliklerden farklı etkinliklere ihtiyaç duyduklarını belirtmiştir. Ayşe, Baki ve Ceren, 5. sınıf düzeyinde uzun süre derse girerek deneyim kazanılacağını belirtmiştir. Bu doğrultuda Ayşe, 11 yıllık meslek süresinde 2 yıl derse girdiği için kendini tecrübesiz görmekte iken, Baki ve Ceren ise ilk zamandan beri 5. sınıf düzeyinde ders verdikleri için yeterliklerinin istenen düzeye ulaştığını ifade etmiştir.

Beşinci sınıf öğrencilerinin yavaş yazma hızı, öğrenme ve problem çözmede yaşanılan farklı durumlarını gelişimsel bir farklılık olarak gören öğretmenler, bu farklılıktan doğan 
zorluğun aşılabilmesi ve sınıf içi bütünlük sağlanabilmesi için farklı metotlar uygulamıştır. 2012 ESD öncesi mezun öğretmenler, derste deftere yazmayı sınıf içi bütünlüğün sağlanabilmesi için zorunlu tutmuştur. 2012 ESD sonrası mezun öğretmenler ise defter tutmayı derste disiplini sağlayabilmek ve sözel çözümlerin kalıcılığı için zorunlu tuttuklarını, bunun yanında öğrencilerin kesme ve yapıştırma etkinlikleriyle sınıf içi disiplin sorunlarının üstesinden gelmeye çalıştıklarını belirtmiştir. Öğrencilerin ilk zamanlarda problemi ve çözümü anlamakta zorlandığını fark eden öğretmenler, bu zorluğu; materyal (Ayşe) ve günlük yaşam örneklerini (Baki ve Ela) kullanarak, anlatımlarında tekrarlı (Doğan), yavaş ve seviyeye inerek (Ceren) aşmaya çalıştıklarını belirtmiştir. Problem çözmede öğrencilerin uygun stratejilere ulaşması için e-öğrenme ortamlarından (Ayşe), kesme ve yapıştırma şeklinde somutlaştırma etkinliklerinden (Baki), geometri araçlarından (Ceren) ve günlük yaşam modellerinden (Ela) yararlanıldığı ifade edilmiştir. Öğretmenler, 5. sınıf öğrencilerinin diğer sınıf düzeylerinden farklı özelliğe sahip olduğunu ve farklı davranışlar gösterdiğini belirtirken, bu düzey için farklı çözüm yolları sergilemenin gerekli olduğunu ve bu yolların zaman aldığını ifade etmiştir.

\section{3. Öğretmenlerin 5. Sınıf Düzeyinde Problem Çözme Yeterliğini Kazanma Durumları}

Öğretmenler, mesleki gelişimleri yoluyla problem çözme yeterliğinin kazanılması süreciyle ilgili genel olarak aldıklanı lisans eğitiminin önemine vurgu yapmış; Ayşe ve Baki, diğer öğretmenlerin ve sosyal ağların; Ceren, kendi tecrübeleri, kitaplar, sosyal ağlar ve üniversitedeki staj eğitiminin; Doğan ise teknolojiye olan ilgisinin mesleki gelişimine katkı sağladığını ifade etmiştir.

Öğretmenlerin sınıf öğretmenleriyle iş birliği yapma durumlarıyla ilgili görüşme sorusuna karş11ık, Baki, Ceren ve Ela, sınıf öğretmenleriyle görüşerek öğrencilerin ön bilgileri ve nasıl öğrendikleri hakkında bilgi aldıklarını ifade etmiştir. Ayşe, kendine yakın hissettiği sınıf öğretmeni olmayışı, yetersiz görme ve görülme endişesi taşıdığı için, Doğan ise bulunduğu okulda sınıf öğretmeni bulunmaması sebebiyle iletişime geçmemiştir. 
Öğretmenlerin hizmet içi eğitimleriyle ilgili olarak, 2012 ESD öncesi mezun öğretmenler hizmet içi eğitime ihtiyaç duyduklarını, fakat bu yönde bir çalışma yapılmadığını; 2012 ESD sonrası mezun öğretmenler, kendilerini yeterli gördükleri için ihtiyaç hissetmediklerini belirtmiştir. Ayşe, hizmet içi eğitim veren kişilerin ders içi realitelerden uzak olduğunu, öğretmenin farklı düzeylerde derse girdikçe gelişebileceğini; Ceren, mesleki gelişimde lisans eğitiminin etkili olması ve kişinin gelişime açık olması gerektiğini; Ela, gelişmek için yenilik ve teknolojiye ayak uydurmak gerektiğini; Doğan da benzer şekilde, öğretmenlerin mesleki gelişimlerini internet, sosyal medya, ayrıca hizmet içi eğitim aracılığıyla sağlayabileceğini belirtmiştir.

Öğretmenler merkezi sınav, müfredat değişiklikleri ve cebirsel çözüm alışkanlıklarının gelişimlerini olumsuz etkilediğini belirtmiştir. Son olarak, öğretmenlerin problem çözme performanslarını etkileyen etmenlerden bir tanesi de problem çözmeyi doğuştan gelen bir yetenek olarak algılama biçimi şeklinde ifade edilmiştir.

\section{SONUÇ, TARTIŞMA VE ÖNERILER}

Bu çalışmada, ortaokul öğretmenlerine yeni yeterlikler gerektiren $4+4+4$ eğitim sistemi (2012 ESD) çerçevesinde, farklı kıdeme sahip beş ortaokul matematik öğretmeninin 5. sınıf düzeyinde kullandıkları problem çözme stratejileri, karşılaştıkları zorluklar ve bu süreçte gelişimlerini nasıl kazandıkları araştırılmıştır.

Öğretmenlerin kullandığı problem çözme stratejileri incelendiğinde, ortaokul kademesindeki somutlsoyut işlemler dönemine uygun olarak mümkün olan çözümleri büyük oranda gerçekleştirebildikleri ve bu durumun öğretmenlerin kıdemleri, ortaokulun farklı düzeylerinde ders verme sürelerine göre benzer olduğu belirlenmiştir. Bu bulgu, Eroğlu ve Tanışlı'nın (2015) problem çözmede temsiller üzerine yaptığı çalışmadaki, deneyimli ve deneyimi az öğretmenlerin problemleri çözme durumlarının benzer olduğu bulgusuyla örtüşmektedir. Bulgular ayrıca, 5. sınıf düzeyinde daha uzun süre derse giren (Baki ve Ceren) 
veya sistem değişikliğinden sonra mezun olan (Doğan ve Ela) öğretmenlerin daha farklı stratejiler sergileyebildiğini göstermiştir.

Öğretmenler, ilk olarak problemleri alışagelmiş oldukları bir yolla çözüme ulaştırmayı, sonrasında ise öğrenciye nasıl anlatacaklarını planlayarak öncelikle başarılı bir çözümü amaçladıklarını ifade etmişlerdir. Öğretmenler bu durumu, eğitim geçmişi ve alışkanlıklarıyla açıklamıştır. Merkezi sınavlarda hızlı çözümler gerektiren bir eleme sistemiyle eğitim hayatını geçirmiş öğretmenler, genellikle cebirsel çözüm yapma eğiliminde olduklarını ve bu durumun eski alışkanlıklarından kaynaklandığını belirtmiştir. Bu bulgu, Tatar, İşleyen ve Okur’un (2005) çalışmasında ulaşılan, sınıf öğretmenlerinin sözel problemlerin çözümünde cebirsel çözümlere yönelmeleri ve cebirsel ifade kullanmaksızın problem çözmede zorlandıkları bulgusuyla paralellik göstermektedir. Hartman (2010) da benzer olarak, öğretmenlerin (kendi) matematiği öğrenme stillerinin sınıf içi uygulamalarda ortaya çıktığını ifade etmektedir. Genellikle bağıntı kullanma ve denklem kurma stratejisi ile çözüme başlayıp hızlı bir çözüm geliştirerek cebirsel bir yol izleyen öğretmenlerin bu yönelimi, Öçal, Şen, Güler ve Kar'ın (2019) çalışmasındaki, öğretmenlerin cebirsel stratejilere daha çok güvendiği bulgusu ile Brumbaugh ve Rock’ın (2013/2017) problem çözme sürecindeki ilk adım olarak, öğretmenin problemi başarılı bir şekilde çözüme ulaştırması ifadesiyle benzerlik göstermektedir. Ayrıca bu bulgu, Gürbüz ve Güder'in (2016), öğretmenlerin problemleri çözerken genellikle sonuç odaklı düşündükleri; Güven, Aydın-Güç ve Özmen'in (2016) öğretmenlerin, öğrencilerin bir problemi yapıp yapamayacağına göre seçimlerini şekillendirmesi ve problemi nasıl sunacağını değil, çözüm ve sonucu nasıl yapacağını önemsemesi bulgularıyla benzerlik göstermektedir.

Öğretmenler, 5. sınıf öğrencilerinin öğretimde ve problem çözmede kullanılan uzun, sözel ifadeleri anlamakta zorlandığını ifade etmiştir. Bu tür sözel ifadelerin öğrencilerde aşamalı bir problem algısı oluşturduğu, öğrencilerin dikkatlerini dağıtarak probleme duyulan ilginin azalmasına sebep olduğu belirlenmiştir. Araştırmanın bu bulgusuna benzer olarak, 
Pusmaz (2008) ve Whittaker-Brown (2002) çalışmalarında, sözel problemleri çözmede okuduğunu anlamanın önemine vurgu yapılarak, öğrencilere bu tür ifadelerin kısa ve yalın sunulmasının başarıyı artıracağı belirtilmektedir. Benzer olarak, Hembree'nin (1992) çalışmasında, derslerde gereğinden çok kelime kullanımının öğrenci başarısını olumsuz etkilediğine vurgu yapılmaktadır. Öğretmenler, 5. sınıf öğrencilerinin anlamakta zorlandığ1 problemleri görsel ögelerle desteklediklerini, bu sayede öğrencilerin daha etkili bir gelişim gösterdiğini belirtmiştir. Ayrıca, öğretmenler 5. sınıf düzeyine uygun problem çözümlerinde, çizim yapma ve benzetim stratejilerini kullandıklarını belirtmiştir. Hembree (1992) çalışmasında, öğrencilerin şekil veya diyagram içeren problemleri çözmede daha başarılı olduklarını ifade etmiştir. Çiftçi ve Temizyürek (2008), 5. sınıf öğrencilerinin okuduğunu anlamada yaşadığı sorunların çözümü için geçmiş yaşantıları ve edinilmiş bilgilerinden hareket etmenin yanında, öğrencilerin problemleri görsellerle desteklemesi ya da bir görseli tarif eder gibi okumalarının etkili olacağını vurgulamaktadır. Boonen, Reed, Schoonenboom ve Jolles (2016), ortaokul matematik öğretmenlerinin sözel problemleri görsel temsiller ile çözmelerini bir yeterlik olarak görmektedir. Öğretmenler, ortaokul matematik dersinde bir probleme ait farklı çözümlerin, daha çok öğrenciye ulaşılabilmesi ve bireysel öğrenme farklılıklarının ortadan kaldırılabilmesi açılarından bir gereklilik olduğunu belirtmiştir. Bulgular, öğretmenlerin ortaokul düzeyi için problem çözme yeterliğine ve strateji çeşitliliğine sahip olduğunu göstermektedir. Benzer bulguya Avcu ve Avcu'nun (2010) çalışmasında rastlanırken, Gürbüz ve Güder'in (2016) çalışmasında ortaokul matematik öğretmenlerinin problem sonucunu bulmada kısmen yeterli olduğu, fakat farklı çözüm stratejileri geliştirmede eksikleri olduğu vurgulanmaktadır.

Çalışmada ayrıca, öğretmenlerin 5. sınıf düzeyinde problem çözme yeterliklerini nasıl kazandıkları araştırılmıştır. 2012 ESD öncesi mezun olan öğretmenler, 5. sınıf düzeyinde hizmet içi eğitim almadıklarını belirtmiştir. Öğretmenler, eksikliklerini gidermede sosyal 
medya ortamında öğretmen takip etme ve bireysel etkileşim yoluna gitmiştir. Demir, Doğan ve Pınar (2013), öğretmenlerin hizmet içi eğitime ihtiyaç duymaksızın, kendi çabalarıyla mesleki gelişimlerini tamamlayarak sınıf düzeyine uygun öğretim faaliyetlerini yürütebildiklerini belirtmiştir. Türk Eğitim Derneği (TED) raporuna göre ise öğretim programı değişikliklerinde öncelikle öğretmenlere hizmet içi eğitimler düzenlenerek mesleki gelişimleri sağlanmalıdır (TED, 2009). Ayrıca hizmet süresi 11-15 yıl olan matematik öğretmenleri hizmet içi eğitime daha çok ihtiyaç duymaktadır (Eğitimi Araştırma ve Geliştirme Dairesi Başkanlığı [EARGED], 2008). 2012 ESD sonrası mezun öğretmenlerin 5. sınıf düzeyinde problem çözme yeterliğine sahip olmasında lisans eğitimlerinin yanında, sosyal ağlar üzerinden diğer öğretmenlerin çalışmalarının etkili olduğu belirlenmiştir. Matematik öğretmenlerinin sınavlara hazırlık kitaplarının takibi, internet ortamında sunulan bilgi ve mesleki uygulamalar öğretmenlerin mesleki gelişimlerinde önemli bir yer tutmaktadır. Bu bulgu, Baş’ın (2016) çalışmasındaki, matematik öğretmenlerinin kişisel gelişimleri için en çok internet kaynağını kullandığı bulgusuyla benzerlik göstermektedir.

Öğretmenlerin yeterliklerini kazanmada etkili olabileceği düşünülen sınıf öğretmeni ile deneyim paylaşımı, genel olarak öğretmenlerin aynı okulda veya yakın arkadaş olması ile sınırlı kalmıştır. Farklı olarak Ayşe öğretmen, sınıf öğretmenlerinin yetersiz olduğunu düşündüğü ve kendisinin de yetersiz görülmesinden kaygılandığı için onlarla iletişim kurmaya çekimser kaldığını belirtmiştir. $\mathrm{Bu}$ bulgular, farklı ortamlardaki öğretmenlerin bir araya gelerek deneyimlerini paylaşmalarının zayıf ihtimaline ve öğretmenlerin kişisel kaygılarının mesleki gelişimleri önünde bir engel oluşturabileceğine işaret etmektedir. Öğretmen kimliğinin kazanılmasında, öğretmenlerin diğer meslektaşlarıyla sağlıklı bir iletişim kurma önemli bir rol oynamaktadır (Saban, 2000). Kepenekçi ve Nayır (2014), öğretmenlerin çekingenlik, tecrübe eksikliğinin yadırganması ve eleştirilmesi gibi sebeplerle diğer öğretmenlerle iletişim kurmakta zorluk yaşadığını belirtmektedir. Çift anadal (sınıf öğretmenliği ve ilköğretim matematik 
öğretmenliği) mezunu Baki, 5. sınıf düzeyine uygun problem çözme ve farklı stratejiler sergileyebilme açısından kendini yeterli hissettiğini belirtmiştir. Bu bulguya benzer olarak, Demir, Doğan ve Pınar (2013), sınıf öğretmenliği lisans eğitimine sahip öğretmenlerin sonradan alan değiştirerek branş öğretmeni olmaları durumunda 5. sınıf düzeyinde zorlanmadıklarını belirtmektedir.

Sonuç olarak bu araştırma, eğitim sistemi değişikliklerinin lisans eğitimi ile uyumlu olmadığı ve uygulama ağırlıklı hizmet içi etkinliklerle desteklenmediği durumlarda, öğrencilerin gelişimlerine uygun öğrenme etkinliklerinin gerçekleşmesinin öğretmenin kendi çaba ve inisiyatifine bağlı olduğunu ortaya koymaktadır. Araştırma sonuçlarından yola çıkarak uygulama ve araştırmalara yönelik bazı öneriler getirilebilir. Ortaokul öğretmenlerine 5. sınıf öğrencilerinin özelliklerine yönelik alan uzmanları tarafından hizmet içi eğitim faaliyetlerinin düzenlenmesi; sosyal ağları ve yenilikçi teknolojileri daha etkin kullanmayı destekleyen eğitimlerin verilmesi; öğretmen kılavuzu ya da uygulama kitaplarının yaygınlaştırılması önem taşımaktadır. Öğretmenlerin problem çözme ve yeterliklerini konu alan çalışmalar farklı düzey ve konularda yaygınlaştırılabilir, ayrıca öğrenci başarısı ile ilişkilendirilebilir.

\section{KAYNAKLAR}

Altun, M. (2008). İlköğretim İkinci Kademede (6, 7 ve 8. Sinıflarda) Matematik Öğretimi. Aktüel Yayıncılık.

Avcu, S., \& Avcu, R. (2010). Pre-service elementary mathematics teachers' use of strategies in mathematical problem solving. Procedia-Social and Behavioral Sciences, 9, 12821286.

Baş, F. (2016). Pre-service elementary mathematics teachers' metaphors on scientific research and foundations of their perceptions. International Education Studies, 9(4), $27-41$. 
Blum, W., \& Niss, M. (1991). Applied mathematical problem solving, modelling, applications, and links to other subjects-state, trends and issues in mathematics instruction. Educational Studies in Mathematics, 22 (1), 37-68.

Boonen, A. J., Reed, H. C., Schoonenboom, J., \& Jolles, J. (2016). It's not a math lesson-we're learning to draw! Teachers' use of visual representations in instructing word problem solving in sixth grade of elementary school. Frontline Learning Research, 4 (5), 55-82.

Brumbaugh, D. K., \& Rock, D. (2017). Lise matematik öğretimi. (Z. Y1lmaz, S. Baştürk, \& H. Kılıç Çev.). Nobel Yayıncılık. (Eserin orijinali 2013'de yayımlanmıştır).

Charles, R., \& Lester F. (1984). An Evaluation of a Process-Oriented Instructional Program in Mathematical Problem Solving in Grades 5 and 7. Journal for Research in Mathematics Education, 15 (1), 15-34.

Çiftçi, Ö., \& Temizyürek, F. (2008). İlköğretim 5. sınıf öğrencilerinin okuduğunu anlama becerilerinin ölçülmesi. Mustafa Kemal Üniversitesi Sosyal Bilimler Enstitüsü Dergisi, 5 (9), 109-129.

Demir, S. B., Doğan, S., \& Pınar, M. A. (2013). 4+4+4 Yeni eğitim sistemi'nin yansımaları: Beşinci sınıflardaki eğitim-öğretim sürecinin branş öğretmenlerinin görüşleri doğrultusunda değerlendirilmesi. Turkish Studies (Elektronik), 8(9 a), 1081-1098.

Eğitimi Araştırma ve Geliştirme Dairesi Başkanlığı (EARGED). (2008). İlköğretim okullarında görev yapan matematik öğretmenlerinin hizmet içi eğitim ihtiyaçları. MEB Yayınları.

Eroğlu, D., \& Tanışlı, D. (2015). Ortaokul matematik öğretmenlerinin temsil kullanımına ilişkin öğrenci ve öğretim stratejileri bilgileri. Necatibey Ĕ̆itim Fakültesi Elektronik Fen ve Matematik Ĕgitimi Dergisi, 9 (1). 275-307.

Gökkurt Özdemir, B., Erdem, E., Örnek, T., \& Soylu, Y. (2017). Are middle school mathematics teachers able to solve word problems without using variable? International Journal of Mathematical Education in Science and Technology, 49(1), 85-106. 
Gürbüz, R., \& Güder, Y. (2016). Matematik öğretmenlerinin problem çözmede kullandıkları stratejiler. Kırşehir Eğitim Fakültesi Dergisi, 17(2).

Güven, B., Aydın-Güç, F., \& Özmen, Z. M. (2016). Problem types used in math lessons: The relationship between student achievement and teacher preferences. International Journal of Mathematical Education in Science and Technology, 47 (6), 863-876.

Hartman, D. R. (2010). A case study of the mathematical learning of two teachers acquiring mathematical knowledge for teaching [Doctoral dissertation, Nebraska-Lincoln University]. https://digitalcommons.unl.edu/cehsdiss/90

Haylock, D., \& Cockburn, A. (2014). Küçük çocuklar için matematiği anlama. (Z. Yılmaz, Çev.). Nobel Yayıncılık. (Eserin orijinali 2013'de yayımlanmıştır).

Hembree, R. (1992). Experiments and relational studies in problem solving: A meta-analysis. Journal for Research in Mathematics Education, 23 (3) 242-273.

Kepenekçi, Y. K., \& Nayır, K. F. (2014). Okul iklimini insan haklarına duyarlılık boyutunda sorgulama: liseler üzerine bir araştırma. Trakya Üniversitesi Eğitim Fakültesi Dergisi, $4(1), 1-16$.

Loucks-Horsley, S., Hewson, P. W., Love, N., \& Stiles, K. E. (1998). Designing professional development for teachers of science and mathematics. Corwin Press.

Ma, L. (1999). Knowing and teaching elementary mathematics: Teachers understanding of fundamental mathematics in china and the united states. Erlbaum.

Merriam, S. B. (2015). Nitel araştırma yöntemleri: Tasarım ve uygulama için bir rehber. (S. Turan, Çev. Ed.). Nobel Yayıncılık. (Eserin orijinali 2009'da yayımlanmıştır).

Milli Eğitim Bakanlığı (MEB). (2012). 12 Yıllık zorunlu eğitime yönelik uygulamalar. 2012/20 Sayll Genelge. http://www.meb.gov.tr/haberler/2012/12YillikZorunluEgitimeYonelikGenelge.pdf. Erişim tarihi: 20.03.2021. 
Millî Eğitim Bakanlığı (MEB). (2018). Matematik dersi öğretim programı (ilkokul ve ortaokul 1, 2, 3, 4, 5, 6, 7 ve 8. siniflar). MEB Yayınları.

Owens, K., \& Perry, B. (2001). Executive summary of mathematics K-10 literature review. https://pdfs.semanticscholar.org/3b86/ca2dd1d096e271610dafa0259307a77c0b50.pdf. Erişim tarihi: 20.05.2018.

Öçal, M. F., Şen, C., Güler, G., \& Kar, T. (2019). The investigation of prospective mathematics teachers' non-algebraic solution strategies for word problems. International Journal of Mathematical Education in Science and Technology, 1-22.

Öğretmen Yetiştirme ve Geliştirme Genel Müdürlüğü (ÖYEGM). (2018). 2001-2017 yıllarında planlanan faaliyet bilgileri. http://oygm.meb.gov.tr/www/icerik_goruntule.php?KNO=28.

Erişim tarihi: 20.05.2018.

Peterson, P., Fennema, E., \& Carpenter, T. (1988). Using knowledge of how students think about mathematics. Educational Leadership, 46 (4), 42-46.

Piaget, J. (1971). Biologie et connaissance: Essai sur les relations entre les regulations organiques et les processes cognitifs (Biyology and knowledge: An essay on the relations between organic regulations and cognitive processes). University of Chicago Press.

Polya, G. (1997). Nasıl çözmeli? (F. Halatçı, Çev.). Sistem Yayıncılık. (Eserin orijinali 1957'de yayınlanmıştır).

Posamentier, A. S., \& Krulik, S. (2016). Matematikte problem çözme 3-6. sinıflar için. (L. Akgün, T. Kar, \& M. F. Öçal, Çev.). Pegem Akademi Yayıncılık. (Eserin orijinali 2009'da yayınlanmıştır).

Pusmaz, A. (2008). Matematik öğretmenlerinin problem çözme sürecinin belirlenmesi ve bu sürecin geliştirilmesinde web tabanlı mesleki gelişim çalışmalarının değerlendirilmesi. 
(Yayın No. 228969) [Yüksek lisans tezi, Marmara Üniversitesi]. YÖK. https://tez.yok.gov.tr

Reuter, T., Schnotz, W., \& Rasch, R. (2015). Drawings and tables as cognitive tools for solving non-routine word problems in primary school. American Journal of Educational Research, 3(11), 1387-1397.

Saban, A. (2000). Hizmet içi eğitimde yeni yaklaşımlar. Milli Eğitim Dergisi, 145, 25-30.

Schoenfeld, A. H. (1989). Explorations of students' mathematical beliefs and behavior. Journal For Research in Mathematics Education, 20(4), 338-355.

Shulman, L. S. (1987). Knowledge and teaching: foundations of the new reform. Harvard Educational Review, 57(1), 1-22.

Soylu, Y. (2010). The models used by elementary school teachers to solve verbal problems. Australian Journal of Teacher Education, 35(4), 3.

Talim ve Terbiye Kurulu Başkanlığı (TTKB). (2017). Müfredatta yenileme ve değişiklik çabalarımız üzerine.

https://ttkb.meb.gov.tr/meb_iys_dosyalar/2017_07/18160003_basin_aciklamasiprogram.pdf. Erişim tarihi: 20.03.2021.

Tatar, E., İşleyen T., \& Okur, M. (2005). Are the primary school teachers of the future ready to solve the word problems without algebra? Research in Mathematical Education, 9(4), 317-328.

Türk Eğitim Derneği (TED). (2009). Öğretmen yeterlikleri. Türk Eğitim Derneği.

Türkiye Yeterlikler Çerçevesi [TYÇ]. (2016). Türkiye yeterlilikler çerçevesine (TYÇ) dair tebliğ ve eki Türkiye yeterlilikler çerçevesi, T.C. Resmî Gazete Sayısı: 29581, http://www.resmigazete.gov.tr. Erişim tarihi: 20.05.2018. 
Van de Walle, J. A., Karp, K. S., \& Bay-Williams, J. M. (2012). Illkokul ve ortaokul matematiği: Gelişimsel yaklaşımla öğretim. (S. Durmuş, Çev. Ed.). Nobel Yayıncılık. (Eserin orijinali 2010 'da yayınlanmıştır).

Wadsworth, B. J. (2015). Piaget `nin duyuşsal ve bilişsel gelişim kuramı (Z. Selçuk, Çev. Ed.). Pegem Akademi Yayıncılık. (Eserin orijinali 1985'te yayınlanmıştır).

Whittaker-Brown, A. N. W. (2002). Strategies for success in mathematics problem-solving: Perspectives of third-grade teachers and students in an urban elementary school. https://elibrary.ru/item.asp?id=5246557. Erişim tarihi: 20.05.2018.

Yıldırım, A., \& Şimşek, H. (2006). Sosyal bilimlerde nitel araştırma yöntemleri. Seçkin Yayıncilık. 


\section{EXTENDED ABSTRACT}

\section{Introduction}

With the 4+4+4 reform of 2012 in the educations system in Turkey, the fifth grade was moved from the primary level to the lower secondary level. As a result, middle school mathematics teachers started to give teach levels that they were not trained for. Therefore, the necessity arose for middle school mathematics teachers to perform learning activities compatible with the concrete operational stage in which the 5th grade students are included.

Mathematics teaching should ensure that students who can see mathematical concepts and the relationships between them, apply the necessary strategies, make logical inferences with what they have learned and solve problems with the help of these (Schoenfeld, 1989). During the problem-solving process, students have difficulties in understanding and expressing problems with mathematical modeling (Reuter, Schnotz \& Rasch, 2015). Teachers play an important role in understanding and modeling the problem. Teachers should consider students' cognitive characteristics and knowledge in the selection of problem-solving strategies. Teachers' use of different strategies in the problem-solving process and providing appropriate solutions for the cognitive stage in which students are involved make significant contributions to mathematics teaching in many ways (Shulman, 1987). Teachers who know how to teach problem-solving can help raise more successful students with different teaching strategies they use in the classroom environment (Peterson, Fennema \& Carpenter, 1988). In other words, students who improve their mathematics knowledge have teachers who use their mathematics knowledge well (Ma, 1999).

In the literature on mathematics education, there are many studies on the problemsolving skills of teachers and prospective teachers, but few studies have been found on the strategies that teachers prefer in the problem-solving process in relation to their professional development in this field. In studies on teachers or pre-service teachers, in general, in the field 
of classroom and primary school mathematics teaching, problem solving without using variables in verbal problems (Gökkurt Özdemir, Erdem, Örnek \& Soylu, 2017; Soylu, 2010; Tatar, Processed \& Okur, 2005) and strategy in problem-solving, or the diversity in the use of representation was examined (Avcu \& Avcu, 2010; Gürbüz \& Güder, 2016; İpek \& Okumuş, 2012; Pusmaz, 2008). To the researchers' knowledge, there have been no studies on the experience and competencies of mathematics teachers in the field of problem-solving who encounter students at the concrete operational stage for the first time. The current study aims to analyze problem-solving strategies that middle school mathematics teachers use in 5th grade, the difficulties they encounter, and how they develop them, in the context of the 2012 education reform.

\section{Method}

The method of the research was determined as a case study, one of the qualitative research methods, in accordance with its aim and the problem it addresses. The research group was formed with five middle school mathematics teachers who graduated before and after 2012 when middle school teachers started teaching in 5th grade for the first time with the implementation of the $4+4+4$ education system. The data collection tools used are as follows: a problem-solving test that includes four non-routine problems on which teachers could apply their strategies proper for concrete and formal operational stage, an interview form intended for teachers' solutions to the difficulties they face in their first year teaching problem solving at the 5th grade class and another interview form intended for teachers' professional competence and their progress. In terms of reliability, the teachers were put in a quiet environment to perform the tasks. Any equipment that could be necessary for the solutions was available to the teachers and audio, video recordings of the exhibited solutions were taken. The data were transcribed without any editing and the analysis was conducted using the qualitative data analysis method of descriptive analysis. 


\section{Results and Conclusion}

In this study, within the framework of the 4+4+4 education system (2012 ESD), which requires new competencies for middle school teachers, the problem-solving strategies that five middle school mathematics teachers of different seniority use at the 5th grade level, the difficulties they encounter, and how they gain their development in this process were investigated.

When the problem-solving strategies used by the teachers were examined, it was determined that they could realize the possible solutions to a large extent in accordance with the concrete/abstract operational stages at the middle school level, and this situation was similar according to the seniority of the teachers and the duration of teaching at different levels of the middle school. The findings also showed that teachers who attended classes for a longer time at the 5th grade level or who graduated after the system change could exhibit different strategies.

Teachers stated that they first solved the problems in a way they were accustomed to, and then planned how they would explain it to the student and aimed at a successful solution first. Teachers explained this situation with their educational background and habits. Teachers who have spent their education life with an elimination system that requires quick solutions in central exams stated that they tend to make algebraic solutions, and this is due to their old habits. This finding is in parallel with the finding in Tatar, Isslenen, and Okur's (2005) study that primary school teachers tend toward algebraic solutions in solving verbal problems and they have difficulties in solving problems without using algebraic expressions. Hartman (2010) similarly states that teachers' (own) mathematics learning styles emerge in classroom practices. This orientation of teachers, who start solving with the strategy of using correlations and formulating equations and follow an algebraic path by developing a quick solution, is similar to the finding of teachers in the study of Öçal, Şen, Güler, and Kar (2019) that they rely more 
on algebraic strategies, and Brumbaugh and Rock (2013/2017) is similar to the statement that the teacher successfully solves the problem as the first step in the problem solving process.

Teachers stated that 5th grade students have difficulty in understanding long, verbal expressions used in teaching and problem solving. It has been determined that such verbal expressions create a gradual problem perception in students and interest in the problem by distracting students. Similar to this finding of the research, Pusmaz's (2008) and WhittakerBrown's (2002) studies emphasize the importance of reading comprehension in solving verbal problems, and it is stated that presenting such expressions to students in a short and simple way will increase success. Similarly, Hembree's (1992) study emphasizes that using too many words in lessons negatively affects student achievement. The teachers stated that they supported the problems that the 5th grade students had difficulty in understanding with visual elements so that the students showed a more effective development. Additionally, the teachers stated that they used drawing and simulation strategies in solving problems suitable for the 5th grade level. Hembree (1992) stated that students were more successful in solving problems involving figures or diagrams. Çiftçi and Temizyürek (2008) emphasize that to solve the problems experienced by 5th grade students in reading comprehension, in addition to using their past experiences and acquired knowledge, it will be effective for students to support problems with visuals or to read as if they are describing an image. Boonen, Reed, Schoonenboom, and Jolles (2016) consider it a competency for middle school mathematics teachers to solve verbal problems with visual representations. Teachers stated that different solutions to a problem in middle school mathematics courses are a necessity in terms of reaching more students and eliminating individual learning differences. Findings show that teachers have problem-solving proficiency and various strategies for middle school level. Similar findings were found in Avcu and Avcu's (2010) study, it is emphasized in Gürbüz and Güder's (2016) study that middle 
school mathematics teachers are partially sufficient in finding the solution to the problem, but they have deficiencies in developing different solution strategies.

The study also investigated how teachers acquired their 5th grade problem-solving competencies. Teachers who graduated before the 2012 ESD stated that they did not receive inservice training at the 5 th grade level. Teachers followed the teacher and individual interaction in the social media environment to overcome their deficiencies. Demir, Doğan, and Pınar (2013) stated that teachers can conduct teaching activities appropriate for the class level by completing their professional development with their efforts, without the need for in-service training. According to the report of the Turkish Education Association (TED), in the curriculum changes, first, teachers should be provided with in-service training and their professional development should be provided (TED, 2009). Additionally, mathematics teachers with 11-15 years of service need in-service training more (Education Research and Development Department [EARGED], 2008). It has been determined that, in addition to undergraduate education, the work of other teachers through social networks is effective in the 5th grade problem-solving competence of graduate teachers after 2012 ESD. The follow-up of mathematics teachers' exam preparation books, the information, and professional practices presented on the Internet has an important place in the professional development of teachers. This finding is similar to that of Baş's (2016) study, which found that mathematics teachers mostly use internet resources for their personal development.

The sharing of experience with the classroom teacher, which is thought to be effective in gaining the teachers' qualifications, was limited to the teachers being in the same school or close friends. Differently, Ayşe stated that she hesitated to communicate with them because she thought that her class teachers were inadequate, and she was worried that she would be seen as inadequate. These findings indicate that teachers from different environments are less likely to come together and share their experiences, and teachers' concerns is an obstacle to their 
professional development. Healthy communication between teachers and colleagues plays an important role in gaining the identity of a teacher (Saban, 2000). Kepenekçi and Nayır (2014) state that teachers have difficulties in communicating with other teachers due to reasons such as shyness, lack of experience, and criticism. Baki, a double major (classroom teacher and primary school mathematics teacher) graduate, stated that he felt competent in problem solving and exhibiting different strategies suitable for the 5th grade level. Similar to this finding, Demir, Doğan, and Pınar (2013) state that teachers with undergraduate education in classroom teaching do not have difficulty at the 5th grade level if they change their field and become branch teachers.

This study has revealed that in cases where educational system changes are incompatible with undergraduate education and are not supported by in-service training, learning activities appropriate to the student level depends on the teachers' effort and initiative. Based on the results of the study, some suggestions can be made. Organizing in-service training activities for middle school teachers by field experts for the characteristics of 5 th grade students; providing training that supports a more effective use of social networks and innovative technologies. Studies on problem solving and competencies of teachers can be disseminated at different levels and subjects, and they can also be associated with student success. 


\section{YAYIN ETİĞİ BEYANI}

Bu araştırmanın, Sakarya Üniversitesi Etik Kurulu Başkanlığı tarafından 03/01/2018 tarihinde 61923333/663.01/78/13 sayılı kararıyla verilen etik kurul izni bulunmaktadır.

$\mathrm{Bu}$ araştırmanın planlanmasından, uygulanmasına, verilerin toplanmasından verilerin analizine kadar olan tüm süreçte "Yükseköğretim Kurumları Bilimsel Araştırma ve Yayın Etiği Yönergesi” kapsamında uyulması belirtilen tüm kurallara uyulmuştur. Yönergenin ikinci bölümü olan "Bilimsel Araştırma ve Yayın Etiğine Aykırı Eylemler" başlığı altında belirtilen eylemlerden hiçbiri gerçekleştirilmemiştir. Bu araştırmanın yazım sürecinde bilimsel, etik ve alıntı kurallarına uyulmuş; toplanan veriler üzerinde herhangi bir tahrifat yapılmamıştır. $\mathrm{Bu}$ çalışma herhangi başka bir akademik yayın ortamına değerlendirme için gönderilmemiştir.

\section{ARAȘTIRMACILARIN KATKI ORANI BEYANI}

Araştırmanın bir bölümü, 2018-ICOM (International Conference on Mathematics) konferansında sunulmuş ve 2. yazarın yüksek lisans tezinden türetilmiştir. Bu çalışmada her iki yazar da eşit katkıya sahiptir.

\section{DESTEK VE TEŞEKKÜR}

Araştırmada yer alarak çalışmanın gerçekleştirilmesini sağlayan öğretmenlere teşekkür ederiz.

\section{ÇATIŞMA BEYANI}

Bu çalışmada her iki yazar da ortak katkıya sahip oldukları için herhangi bir çatışma veya görüş ayrılığı bulunmamaktadır. 